\title{
Zeolitas a base de cenizas volantes del Reino Unido como adsorbentes para la remoción de metales pesados y amonio a partir de soluciones contaminadas artificialmente
}

\author{
Carlos A. Ríos ${ }^{* \$}$, Craig D. Williams ${ }^{* * *}$, Clive L. Roberts ${ }^{* *}$ \\ *Escuela de Geología, Universidad Industrial de Santander, Colombia \\ **School of Applied Sciences, University of Wolverhampton, England \\ §email:carios@uis.edu.co
}

(Recibido: Diciembre 17 de 2009- Aceptado:Junio 10 de 2010)

\begin{abstract}
Resumen
Ceniza volante de la Estación de Energía Rugeley, West Midlands (Inglaterra) fue utilizada en este estudio como material de partida en la síntesis de zeolitas a escala de laboratorio usando soluciones de $\mathrm{NaOH}$ y $\mathrm{KOH}$. Na-filipsita, hidroxisodalita y K-chabazita fueron sintetizadas a partir de ceniza volante usando el método hidrotérmico clásico. Las zeolitas a base de ceniza volante fueron usadas como adsorbentes de metales pesados y amonio de soluciones acuosas artificialmente contaminadas con metales seleccionados y otros contaminantes. Finalmente, con el fin de probar sus posibles aplicaciones en la descontaminación de aguas, se investigó la eficiencia de las zeolitas sintetizadas en la retención de metales pesados y amonio de soluciones sintéticas usando reacciones tipo "batch" a temperatura ambiente. Se examinaron parámetros importantes tales como dosis de zeolita $(\mathrm{g})$ por volumen de solución (ml) y tiempo de reacción con el fin de entender los mecanismos de remoción involucrados. La eficiencia de las zeolitas sintetizadas muestra que estas pueden alcanzar capacidades de intercambio catiónico apropiadas para su aplicación en el tratamniento de aguas residuales industriales. La selectividad de metales pesados de la Na-filipsita fue determinada como $\mathrm{Cu}>\mathrm{Zn}>\mathrm{Cr}>\mathrm{Ni}>\mathrm{Pb}$, mostrando también una gran afinidad por $\mathrm{Nh}_{4}{ }^{+}$.
\end{abstract}

Palabras Claves: Cenizas volantes, Síntesis de zeolitas, Metales pesados, Amonio, Retención.

GEOLOGICAL ENGINEERING

\section{UK fly ash-based zeolites as adsorbents for removal of heavy metals and ammonium from artificially polluted solutions}

\begin{abstract}
Fly ash (FA) from the Rugeley Power Station, West Midlands (England) was used in this study as starting material in zeolite synthesis at laboratory scale using $\mathrm{NaOH}$ and $\mathrm{KOH}$ solutions. Na-phillipsite, hydroxysodalite and Kchabazite were synthetized from FA using the classic hydrothermal route. The FA-based zeolites (FAZs) were employed as heavy metal and ammonium adsorbents from aqueous solutions artificially polluted with selected metals and other contaminants. Finally, with the aim of testing possible applications of the FAZs in water decontamination, efficiency for heavy metal and ammonium uptake from synthetic solutions using batch reactions at room temperature was investigated. Important parameters such as zeolite dose $(\mathrm{g})$ per effluent volume unit $(\mathrm{ml})$ and reaction time were examined in order to understand the removal mechanisms involved. The efficiency of the FAZs shows that these FAZs may reach CECs appropriate for their application in industrial wastewater treatment. The heavy metal selectivity of Na-phillipsite was determined as $\mathrm{Cu}>\mathrm{Zn}>\mathrm{Cr}>\mathrm{Ni}>\mathrm{Pb}$, and it also showed a high affinity for $\mathrm{NH}_{4}^{+}$.
\end{abstract}

Keywords: Fly ash, Zeolite synthesis, Heavy metal, Ammonium, Uptake 


\section{Introduction}

FA is a waste substance generated annually in the world from coal combustion by thermal power plants, and its disposal poses major challenges and serious environmental problems. Furthermore, the amount of discharged material is expected to increase in the future. However, FA has been used for reclamation, asphalt shingle production, quarry-fill and sludge stabilization, but most is disposed as landfill. Due to the shortage of landfill sites and stricter environmental regulation, new ways to recycle FA should be quickly developed, and one new way is through the production of zeolites by its alkaline activation, taking into account that $\mathrm{FA}$ has a $\mathrm{SiO}_{2} / \mathrm{Al}_{2} \mathrm{O}_{3}$ ratio appropriate to be used as raw material in zeolite synthesis.

Zeolites are crystalline, porous, hydrated aluminosilicates, with a three-dimensional structure composed by $\left[\mathrm{SiO}_{4}\right]^{4-}$ and $\left[\mathrm{AlO}_{4}\right]^{5-}$ tetrahedra, which corner-share to form different open structures with an overall negative charge, which is balanced by the cations which move freely in and out of their frameworks. Owing to zeolite's framework characteristics and their adsorbent properties, they have been mainly applied in adsorption, ion exchange and catalysts. The conversion of FA to zeolites has been reported by several authors (Höller and Wirsching, 1985; Mondragón et al., 1990; La Rosa et al., 1992; Lin and His, 1995; Singer and Berkgaut, 1995; Shih and Chang, 1996; Amrhein et al., 1996; Querol et al., 2002a; Ojha et al., 2004; Inada et al., 2005; Juan et al., 2007). However, the use of zeolites in environmental remediation is restricted due to procurement problem and prohibitive cost, which can be sorted by using low-cost FAZs. Therefore, FAZs both contributes to the mitigation of environmental problems, generally in the field of wastewater purification, removing heavy metals, and turns waste materials into attractive and useful ones. Heavy metals are released into surface and ground water, damaging the health of plants, wild and aquatic life. Removal of the pollutants from aqueous media, therefore, has received a considerable amount of attention. The potential use of FAZs in water decontamination has been evaluated by a number of research groups and the removal of heavy metals from wastewater has been tested extensively (Moreno et al., 2001; Querol et al., 2002b, Wingenfelder et al., 2005; Gitari et al., 2006). Adsorption has been the preferred method, because it is considered to be a particularly effective technique. Zeolites are relatively low-cost and readily available materials, which possess adsorbent properties and are likely one of the most promising to carry out heavy metal removal. In this paper, we investigate at laboratory-scale the effectiveness of FAZs as adsorbents in removing heavy metals $(\mathrm{Cu}, \mathrm{Pb}, \mathrm{Zn}$, $\mathrm{Ni}$ and $\mathrm{Cr}$ ) and ammonium from artificially polluted solutions.

\section{Experimental methods and materials}

\subsection{Starting materials}

The raw FA used for the synthesis of zeolite-like materials was supplied by the Rugeley Power Station, West Midlands (England), being generated by pulverized coal combustion (PCC) and classified as Class F FA, which is produced from burning anthracite and bituminous coals. All compounds used to activate the FA and to prepare the model solutions were of analytic reagent grade and include the following: sodium hydroxide, $\mathrm{NaOH}$, as pellets $(99 \%$, from Aldrich Chemical Company, Inc.) or powder $(96 \%$, from $\mathrm{BDH}$ GPR), potassium hydroxide, $\mathrm{KOH}$, as pellets (99\%, from Aldrich Chemical Company, Inc.), nitrates such as $\mathrm{Cu}\left(\mathrm{NO}_{3}\right)_{2} \cdot 3 \mathrm{H}_{2} \mathrm{O}, \mathrm{Pb}\left(\mathrm{NO}_{3}\right)_{2}$, $\mathrm{Zn}\left(\mathrm{NO}_{3}\right)_{2} .6 \mathrm{H}_{2} \mathrm{O}, \mathrm{Cr}\left(\mathrm{NO}_{3}\right)_{3} .9 \mathrm{H}_{2} \mathrm{O}$ and $\mathrm{Ni}\left(\mathrm{NO}_{3}\right)_{2} \cdot 6 \mathrm{H}_{2} \mathrm{O}$, ammonium chloride $\left(\mathrm{NH}_{4} \mathrm{Cl}\right)$, acetic acid $\left(\mathrm{CH}_{3} \mathrm{COOH}\right)$, glucose $\left(\mathrm{C}_{6} \mathrm{H}_{12} \mathrm{O}_{6}\right)$, calcium chloride $\left(\mathrm{CaCl}_{2}\right)$, potassium chloride $(\mathrm{KCl})$, monopotassium phosphate $\left(\mathrm{KH}_{2} \mathrm{PO}_{4}\right)$, magnesium sulfate $\left(\mathrm{MgSO}_{4}\right)$, and distilled water using standard purification methods.

\subsection{Synthesis and characterization of zeolite sorbents}

The synthesis of FAZs was investigated by the classic hydrothermal synthesis. Alkali hydroxide pellets were added to distilled water to prepare $\mathrm{NaOH}(1.33$ and $3.99 \mathrm{M})$ or $\mathrm{KOH}(3.99 \mathrm{M})$ solutions. Then, the FA was added to the alkaline solutions with solution/FA ratios of 6.12 and 6.73 $\mathrm{ml} / \mathrm{g}$ using $\mathrm{NaOH}$ and $3.37 \mathrm{ml} / \mathrm{g}$ using $\mathrm{KOH}$. The 
progressive addition of reagents was carried out with stirring until they dissolved to homogenize the reaction gels. The hydrogels were transferred to PTFE bottles of $65 \mathrm{ml}$ for preparations heated at $100^{\circ} \mathrm{C}$ and the crystallization was carried out under static conditions for 48 or 72 hours. pH was measured before and after hydrothermal treatment. The reactors were removed from the oven at the scheduled times and were quenched in cold water. After hydrothermal treatment, the reaction mixtures were filtered and washed with distilled water and the synthesis products were oven dried at $80^{\circ} \mathrm{C}$. The mineral phases in the as-synthesized FAZs were studied by X-ray diffraction (Philips PW1710 diffractometer) operating in BraggBrentano geometry with $\mathrm{Cu}-\mathrm{K} \alpha$ radiation $(40 \mathrm{kV}$ and $40 \mathrm{~mA}$ ) and secondary monochromation. Data collection was carried out in the $2 \theta$ range $3-50^{\circ}$, with a step size of $0.02^{\circ}$. Phase identification was made by searching the ICDD powder diffraction file database, with the help of JCPDS (Joint Committee on Powder Diffraction Standards) files for inorganic compounds. A ZEISS EVO50 scanning electron microscope, equipped with an energy dispersive (EDX) analyzer, was used for microstructural characterization, under the following analytical conditions: I probe $1 \mathrm{nA}$, EHT $=20.00 \mathrm{kV}$, beam current $100 \mu \mathrm{A}$, Signal A $=$ SE1, $\mathrm{WD}=8.0 \mathrm{~mm}$.

\subsection{Adsorption experiments and water analysis}

A weighed amount of each nitrate salt, ammonium chloride and other compounds were dissolved in distilled water to formulate the artificially polluted stock solutions $(1000 \mathrm{mg} / \mathrm{l})$ containing the selected metals. Adsorption tests were conducted using the as-synthesized FAZs and synthetic solutions in order to investigate the heavy metal and ammonium uptake onto the sorbents. Batch experiments were carried out in high density plastic polyethylene containers with a volume capacity of $100 \mathrm{ml}$ through batch type reactions at room temperature, by using a given sorbent dose (sorbent:solution mixture of $0.25,0.5$ and $1 \mathrm{~g} / 20$ $\mathrm{ml}$ or $1 \mathrm{~g} / 50 \mathrm{ml}$ ) and the suspension was kept in a rotary shaker with a constant agitation speed of 150 rpm for a given time interval. In these experiments the sorbent:liquid ratio was varied to investigate the effects of variation of sorbent dose on the metal retention of selected metals with the sorbent. Each sorbent/solution sample was individually placed in separate containers and at the scheduled times each container was removed from the shaker and the filtrate collected by filtering the suspension with a $0.45 \mu \mathrm{m}$ membrane filter, and finally the $\mathrm{pH}$ and EC measured. The resultant leachates were kept in a refrigerator at $4 \mathrm{oC}$ for ICP AES analysis. All measurements were done according to the Standard Methods for the Examination of Water and Wastewater. Analysis of the synthetic solution and the leachates obtained after batch experiments were initially performed using $\mathrm{pH}(\mathrm{pH} 211$ Autocalibration bench $\mathrm{pH} / \mathrm{mV}$ meter - Hanna instruments) and electrical conductivity - EC (Conductivity meter - version Cond 315i - WTW). Dilutions were made using distilled water depending on the original EC of each sample. The equilibrium concentration of heavy metal ions was measured by using a Spectro Ciros ICP-AE Spectrometer. A Photometer 7100 fully integrated with the Palintest water test system was used to measure ammonium over the ranges $0-1.0 \mathrm{mg} / 1 \mathrm{~N}$.

\section{Results and discussion}

\subsection{Characterization of sorbents}

Figure 1 illustrates the XRD patterns of the FAZs used in this study. For shorter reaction times $(3 \mathrm{~h})$, the diffraction intensities of quartz and mullite of the original FA showed a small decrease and zeolitic materials were not detected. With reaction time, the intensities of quartz progressively decreased, whereas those of mullite did not change, indicating that it was a relatively stable phase during the hydrothermal reaction. The presence of zeolitic phases was determined by the appearance of weak reflection peaks, which increase in intensity with reaction time. However, the characteristic XRD peaks of mullite and quartz still remain after $48 \mathrm{~h}$ of hydrothermal reaction, which demonstrated the low reactivity of these phases in alkaline solutions.

Na-phillipsite, with minor hydroxysodalite, were the zeolitic phases obtained after activation of FA in solutions of lower $\mathrm{NaOH}$ concentration (Figure 1a), whereas hydroxysodalite with minor $\mathrm{Na}-$ phillipsite crystallized at higher $\mathrm{NaOH}$ concentration (Figure 1b). The activation of FA in $\mathrm{KOH}$ solutions resulted in the progressive 

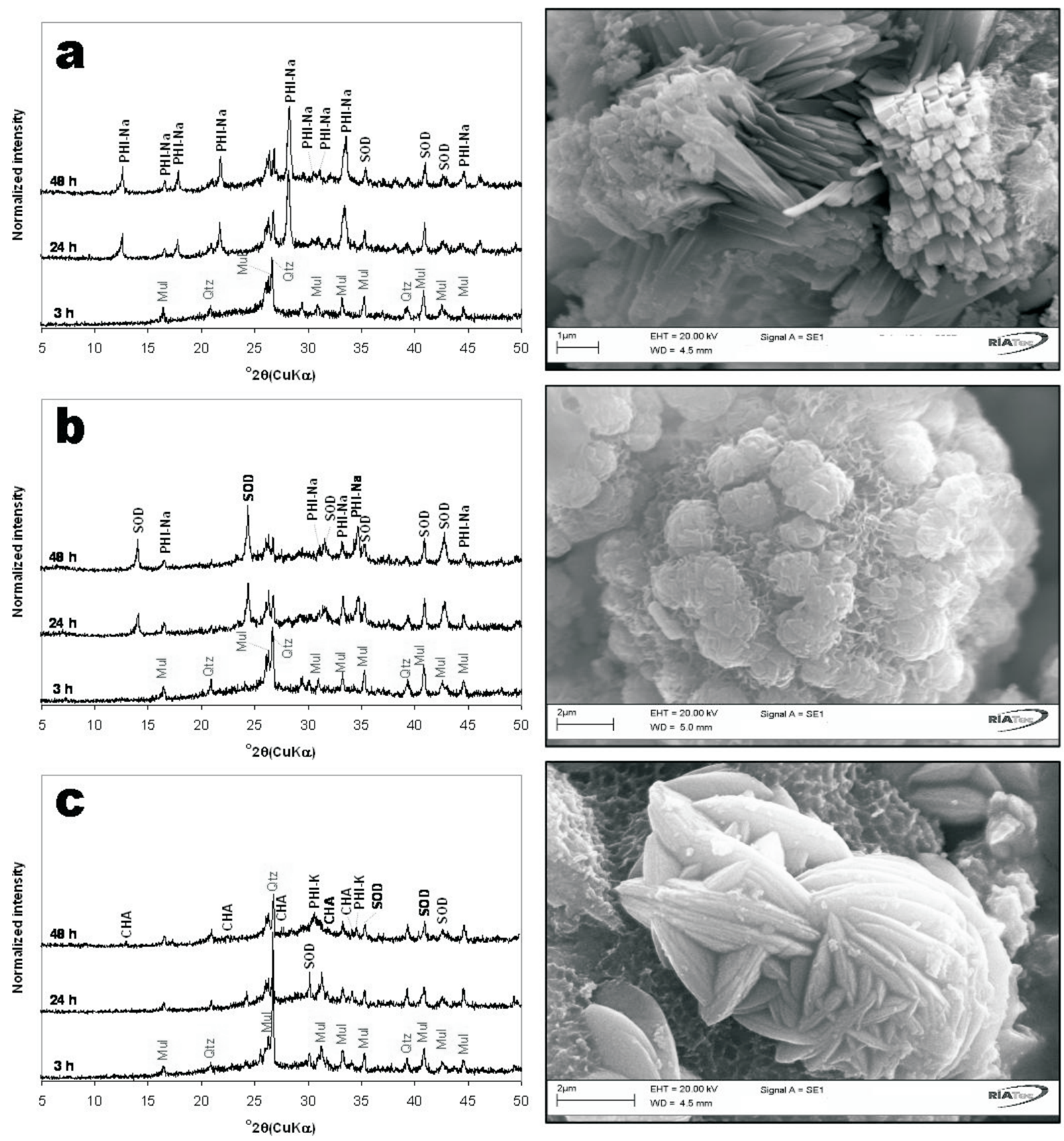

Figure 1. XRD patterns and SEM microphotographs of the as-synthesized FAZs adding FA to alkaline solutions with solution/FA ratios of $6.12 \mathrm{ml} / \mathrm{g}$ (a) and $6.73 \mathrm{ml} / \mathrm{g}$ (b) using $\mathrm{NaOH}$ and 3.37 (c) $\mathrm{ml} / \mathrm{g}$ using $\mathrm{KOH}$. PHI-Na, sodium phillipsite; PHI-K, potassium phillipsite; SOD, hydroxysodalite, CHA, chabazite; Qtz, quartz; Mul, mullite. 
dissolution of quartz and mullite and the corresponding crystallization of K-chabazite, with minor K-phillipsite and hydroxysodalite (Figure 1c). Morphological aspects of the three different FAZs (Figure 1) reveal zeolite crystallization onto the external surface of the original FA particles as pseudomorphs. Large clusters of radiating tetragonal prisms of Na-phillipsite, associated to hydroxysodalite, are observed in Figure 1a. As shown in Figure 1b, hydroxysodalite develops aggregates of randomly oriented and intersecting blade-shaped crystals. Hexagonal plates of Kchabazite with a phacolitic aspect associated to hydroxysodalite is illustrated in Figure 1c.

\subsection{Sorption of metal ions and ammonium from aqueous solutions on the sorbents}

The sorption process considered here refers to a sorbent (FAZ) and a polluted aqueous media containing dissolved metal ions and ammonium to be sorbed. There is a strong 'affinity' of the sorbent for the metal ions, which are attracted into the sorbent and bound there by different mechanisms.

\subsubsection{Treatment using FAZs}

The objective of this laboratory investigation was to evaluate the heavy metal and ammonium removal during a polishing treatment of artificially polluted solutions in order to compare the capacity and selectivity of different sorbents during the treatment process and to confirm that the FAZs have an advantage over other ion exchangers taking into account their much lower cost and ion selectivity. Table 1 summarises the values of $\mathrm{pH}, \mathrm{EC}$ and concentration of metal ions and ammonium of an untreated synthetic solution and those of the leachates obtained by using a sorbent:solution mixture of $0.25 \mathrm{~g} / 20 \mathrm{ml}$ during 300 minutes.

The kinetics of the neutralization reaction was investigated by monitoring the $\mathrm{pH}$ and $\mathrm{EC}$ (Figure 2) of the treated solutions over a period of 300 minutes. The neutralization of the solution (Figure $2 \mathrm{a})$ is initially very rapid, with the $\mathrm{pH}$ increasing from 4.94 to 10.32 (hydroxysodalite), 10.41 (Na-

Table 1. Water quality parameters recorded during 300 minutes of continuous shaking of FAZs with a synthetic solution in closed batch experiments (sorbent:SSA mixture of $0.25 \mathrm{~g} / 20 \mathrm{ml}$ ). SSA, synthetic solution A.

\begin{tabular}{|c|c|c|c|c|c|c|c|c|c|c|c|c|c|c|c|}
\hline \multirow{3}{*}{$\begin{array}{c}\text { Contact time } \\
(\min )\end{array}$} & \multirow{3}{*}{$\begin{array}{c}\mathrm{pH} \\
4.94 \\
\end{array}$} & \multirow{2}{*}{\multicolumn{2}{|c|}{$\mathrm{EC}(\mu \mathrm{S} / \mathrm{cm})$}} & \multicolumn{5}{|c|}{ Heavy metal concentration (ppm) } & \multicolumn{6}{|c|}{ Other element concentration (ppm) } & \multirow{3}{*}{\begin{tabular}{|c|} 
Ammonium (mg/l) \\
7.8
\end{tabular}} \\
\hline & & & & \multirow{2}{*}{$\begin{array}{c}\mathrm{Cu} \\
12.59\end{array}$} & \multirow{2}{*}{$\begin{array}{c}\mathrm{Pb} \\
30.26\end{array}$} & \multirow{2}{*}{$\begin{array}{c}\mathrm{Zn} \\
12.23\end{array}$} & \multirow{2}{*}{$\begin{array}{c}\mathrm{Cr} \\
7.43\end{array}$} & \multirow{2}{*}{$\begin{array}{c}\mathrm{Ni} \\
11.09\end{array}$} & \multirow{2}{*}{$\begin{array}{c}\mathrm{Mg} \\
0.21\end{array}$} & \multirow{2}{*}{$\begin{array}{c}\mathrm{Ca} \\
2.92\end{array}$} & \multirow{2}{*}{$\begin{array}{r}\mathrm{Na} \\
0.07\end{array}$} & \multirow{2}{*}{$\frac{\mathrm{K}}{0.47}$} & \multirow{2}{*}{$\begin{array}{c}\mathrm{Si} \\
0.09\end{array}$} & \multirow{2}{*}{$\begin{array}{c}\text { Al } \\
0.02\end{array}$} & \\
\hline & & 266 & $22.6^{\circ} \mathrm{C}$ & & & & & & & & & & & & \\
\hline \multicolumn{16}{|c|}{ Batch reaction of $\mathrm{Na}$-phillipsite } \\
\hline 5 & 10.41 & 773 & $21.6^{\circ} \mathrm{C}$ & 0.01 & 0.06 & 0.03 & 0.03 & 0.06 & 1.10 & 29.50 & 206.92 & 39.81 & 4.84 & 0.04 & 4.5 \\
\hline 10 & 10.35 & 857 & $21.7^{\circ} \mathrm{C}$ & 0.02 & 0.05 & 0.03 & 0.03 & 0.05 & 1.69 & 36.39 & 205.62 & 40.62 & 5.84 & 0.02 & 4.4 \\
\hline 30 & 10.42 & 986 & $21.9^{\circ} \mathrm{C}$ & 0.01 & 0.02 & 0.02 & 0.02 & 0.04 & 2.15 & 35.66 & 255.80 & 47.42 & 10.63 & 0.27 & 4.6 \\
\hline 45 & 10.38 & 1018 & $21.6^{\circ} \mathrm{C}$ & 0.01 & 0.03 & 0.02 & 0.01 & 0.04 & 3.82 & 62.66 & 263.79 & 53.29 & 14.10 & 0.33 & 3.8 \\
\hline 60 & 10.29 & 1055 & $21.7^{\circ} \mathrm{C}$ & 0.01 & 0.00 & 0.01 & 0.01 & 0.03 & 2.03 & 42.55 & 265.38 & 50.91 & 16.56 & 0.32 & 3.4 \\
\hline 120 & 10.45 & 1086 & $21.9^{\circ} \mathrm{C}$ & 0.01 & 0.00 & 0.01 & 0.00 & 0.03 & 1.35 & 38.10 & 253.24 & 47.97 & 21.16 & 0.39 & 2.2 \\
\hline 180 & 10.28 & 1200 & $22.4^{\circ} \mathrm{C}$ & 0.01 & 0.06 & 0.01 & 0.02 & 0.01 & 2.64 & 57.09 & 283.82 & 51.67 & 25.41 & 0.74 & 1.7 \\
\hline 240 & 10.20 & 1184 & $22.7^{\circ} \mathrm{C}$ & 0.02 & 0.04 & 0.01 & 0.02 & 0.01 & 3.70 & 75.25 & 299.58 & 67.25 & 28.52 & 0.65 & 1.2 \\
\hline 300 & 10.09 & 1219 & $23.3^{\circ} \mathrm{C}$ & 0.02 & 0.09 & 0.02 & 0.03 & 0.00 & 2.43 & 67.10 & 318.23 & 49.25 & 30.33 & 0.87 & 1.1 \\
\hline \multicolumn{16}{|c|}{ Batch reaction of hydroxysodalite } \\
\hline 5 & 10.32 & 695 & $21.5^{\circ} \mathrm{C}$ & 0.01 & 0.05 & 0.02 & 0.03 & 0.02 & 1.71 & 58.64 & 163.68 & 33.57 & 3.86 & 0.06 & 6.4 \\
\hline 10 & 10.42 & 777 & $21.8^{\circ} \mathrm{C}$ & 0.02 & 0.02 & 0.02 & 0.03 & 0.04 & 2.33 & 77.46 & 188.66 & 39.49 & 5.51 & 0.05 & 6.5 \\
\hline 30 & 10.51 & 916 & $21.7^{\circ} \mathrm{C}$ & 0.02 & 0.03 & 0.02 & 0.03 & 0.05 & 1.43 & 46.15 & 232.72 & 38.31 & 10.57 & 0.03 & 6.9 \\
\hline 45 & 10.48 & 995 & $21.8^{\circ} \mathrm{C}$ & 0.01 & 0.05 & 0.20 & 0.03 & 0.26 & 1.94 & 61.49 & 259.35 & 51.23 & 13.33 & 0.01 & 5.5 \\
\hline 60 & 10.46 & 1062 & $21.8^{\circ} \mathrm{C}$ & 0.02 & 0.01 & 0.02 & 0.03 & 0.04 & 1.86 & 53.22 & 244.27 & 33.21 & 15.80 & 0.08 & 4.7 \\
\hline 120 & 10.50 & 1079 & $21.8^{\circ} \mathrm{C}$ & 0.01 & 0.01 & 0.02 & 0.02 & 0.04 & 1.87 & 73.13 & 267.64 & 43.77 & 21.57 & 0.03 & 2.5 \\
\hline 180 & 10.37 & 1271 & $22.3^{\circ} \mathrm{C}$ & 0.01 & 0.00 & 0.01 & 0.02 & 0.03 & 2.32 & 99.29 & 317.65 & 52.28 & 25.40 & 0.47 & 1.5 \\
\hline 240 & 10.21 & 1238 & $22.5^{\circ} \mathrm{C}$ & 0.01 & 0.01 & 0.01 & 0.02 & 0.03 & 1.67 & 135.95 & 301.31 & 57.06 & 23.12 & 0.06 & 1.2 \\
\hline 300 & 10.00 & 1294 & $23.1^{\circ} \mathrm{C}$ & 0.00 & 0.02 & 0.01 & 0.01 & 0.03 & 4.56 & 155.01 & 359.41 & 86.12 & 26.66 & 0.20 & 0.9 \\
\hline \multicolumn{16}{|c|}{ Batch reaction of $K$-chabazite } \\
\hline 5 & 10.46 & 1076 & $21.7^{\circ} \mathrm{C}$ & 0.01 & 0.04 & 0.03 & 0.03 & 0.04 & 2.16 & 3.75 & 65.81 & 368.04 & 4.00 & 0.00 & 6.1 \\
\hline 10 & 10.42 & 1124 & $21.6^{\circ} \mathrm{C}$ & 0.02 & 0.04 & 0.03 & 0.03 & 0.05 & 2.53 & 4.37 & 70.82 & 373.76 & 4.72 & 0.03 & 6.0 \\
\hline 30 & 10.46 & 1239 & $21.9^{\circ} \mathrm{C}$ & 0.02 & 0.06 & 0.03 & 0.03 & 0.04 & 2.76 & 2.61 & 66.30 & 431.73 & 7.28 & 0.03 & 6.8 \\
\hline 45 & 10.45 & 1279 & $21.8^{\circ} \mathrm{C}$ & 0.02 & 0.05 & 0.03 & 0.03 & 0.04 & 2.02 & 0.96 & 66.21 & 440.97 & 9.15 & 0.03 & 5.0 \\
\hline 60 & 10.34 & 1351 & $21.7^{\circ} \mathrm{C}$ & 0.01 & 0.01 & 0.03 & 0.02 & 0.05 & 2.42 & 1.72 & 67.00 & 496.84 & 11.07 & 0.03 & 4.1 \\
\hline 120 & 10.67 & 1411 & $21.5^{\circ} \mathrm{C}$ & 0.02 & 0.03 & 0.03 & 0.02 & 0.04 & 1.99 & 8.35 & 68.80 & 495.15 & 13.73 & 0.00 & 2.4 \\
\hline 180 & 10.35 & 1466 & $22.5^{\circ} \mathrm{C}$ & 0.01 & 0.00 & 0.02 & 0.01 & 0.04 & 1.85 & 2.97 & 63.88 & 504.14 & 15.47 & 0.01 & 1.5 \\
\hline 240 & 10.32 & 1484 & $22.7^{\circ} \mathrm{C}$ & 0.01 & 0.01 & 0.02 & 0.01 & 0.04 & 2.17 & 2.78 & 65.46 & 537.70 & 16.11 & 0.02 & 1.3 \\
\hline 300 & 10.09 & 1506 & $23.3^{\circ} \mathrm{C}$ & 0.00 & 0.02 & 0.01 & 0.01 & 0.03 & 4.92 & 2.49 & 72.48 & 562.58 & 17.34 & 0.14 & 1.2 \\
\hline
\end{tabular}



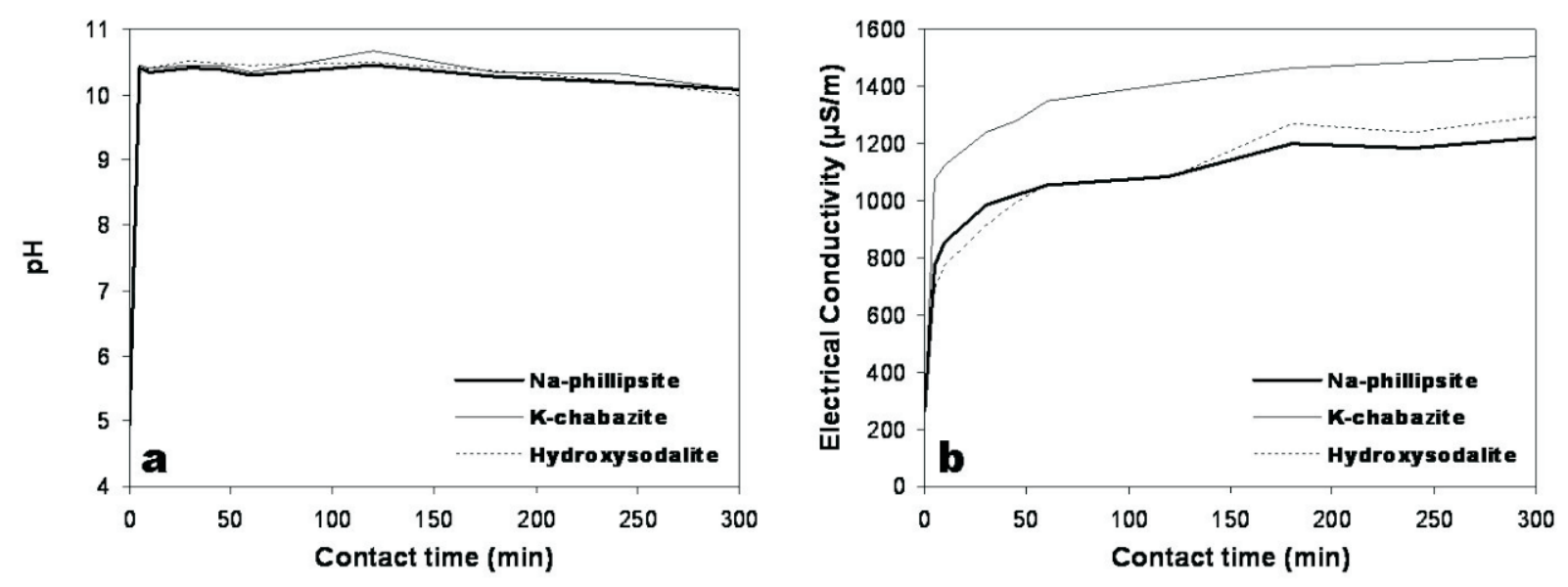

Figure 2. pH (a) and EC (b) variation as a function of time during the adsorption batch experiments with starting pH of 4.94 and EC of $266 \mu \mathrm{S} / \mathrm{cm}$, sorbent (FAZ) dose of $0.25 \mathrm{~g}$, and SSA volume of $20 \mathrm{ml}$. SSA, synthetic solution A.

phillipsite) and 10.46 (K-chabazite) within 5 minutes. Breakthrough to alkaline $\mathrm{pH}$ was obtained at 5 minutes of contact, and the FAZs produced similar $\mathrm{pH}$ trends. The reaction rates decrease as equilibrium is approached. The $\mathrm{pH}$ was stabilized within 1 hour and then it shows a progressive decrease. Final $\mathrm{pH}$ values range from 10.00 to 10.09 and are similar to those obtained in our batch experiments have been attributed to hydrolysis of zeolites as well as cationic exchange (Genç-Fuhrman et al., 2007). According to Ouki and Kavannagh (1997) and Pitcher et al. (2004), the $\mathrm{pH}$ increase is almost unavoidable in a zeolite heavy metal system. EC (Figure 2b) ranges from 773 to 1219 (Na-phillipsite), from 695 to 1294 (hydroxysodalite) and from 1076 to 1506 (Kchabazite) $\mu \mathrm{S} / \mathrm{cm}$. The synthesis products produced similar EC trends, although K-chabazite reached higher EC values.

The addition of zeolite raised the $\mathrm{pH}$ in all the experiments. As the $\mathrm{pH}$ rises, the solutions become supersaturated for certain solid phases which could precipitate. However, this study should be complimented to determine whether the decrease in metal concentration is due to cation exchange or to solid precipitation. Adsorption is thus ascribed to be a surface effect rather than involving incorporation into the channels of the zeolite structure (Woolard et al., 2002).

Figure 3 shows the ammonium trends corresponding to the FAZs, which are characterized by a reversible behaviour, with a sudden decrease from 7.8 to 4.5 (Na-phillipsite), 6.4 (hydroxysodalite) and 6.1 (K-chabazite) $\mathrm{mg} / \mathrm{l}$ of ammonium after 5 minutes, increasing from 5 to 30 minutes, and finally decreasing with reaction time. In general, the ammonium trends are similar, particularly after 2 hours, although also at shorter reaction time Na-phillipsite displays the highest efficiency in ammonium removal. However, a complete removal of ammonium after 5 hours was not obtained.

The removal trends of heavy metals in the final leachates for the investigated FAZs are shown in Figures $4 \mathrm{a}, 4 \mathrm{~d}$ and $4 \mathrm{~g}$. Cr shows a similar behaviour with an abrupt drop in concentration during the first 5 minutes, a small increase between 5 and 10 minutes and finally showing a progressive decrease with reaction time when hydroxysodalite and K-chabazite were used. However, the lowest concentration of $\mathrm{Cr}$ was obtained after 2 hours of reaction using $\mathrm{Na}$ phillipsite and then a progressive increase with reaction time occurred, indicating a reversible character. $\mathrm{Cu}$ and $\mathrm{Zn}$ show a similar behaviour to that displayed by $\mathrm{Cr}$ during the first 10 minutes. $\mathrm{Ni}$ also shows an abrupt drop in concentration during the first 5 minutes, but an sudden increase occurred between 5 and 10 minutes using hydroxysodalite and K-chabazite. It shows a progressive reduction with reaction time using Na-phillipsite, and it probably can be totally removed at longer reaction times. However, Ni shows a strongly reversible character when hydroxysodalite and $\mathrm{K}$-chabazite were used as 


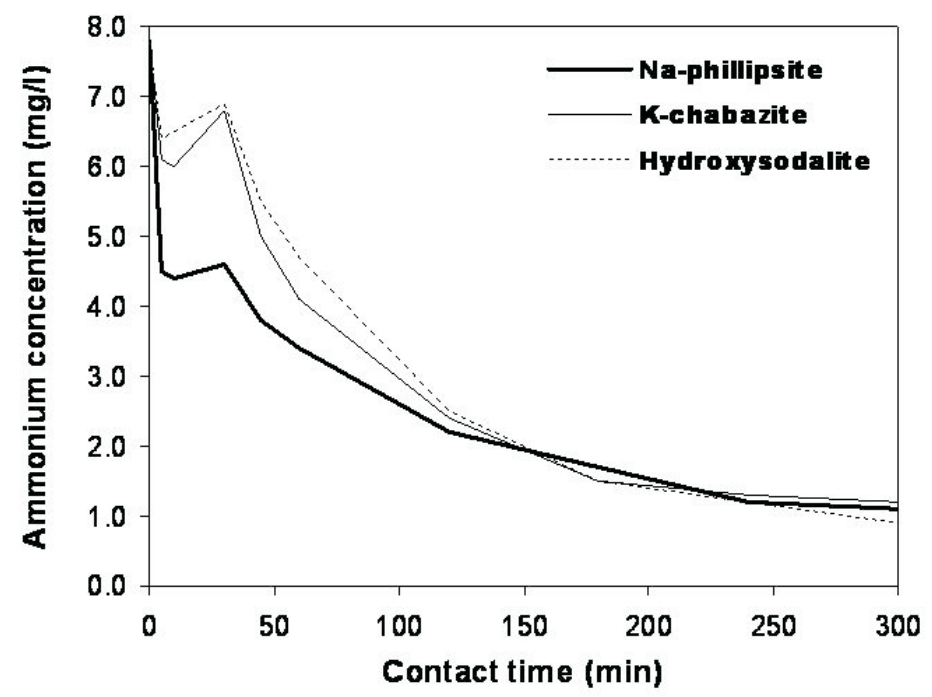

Figure 3. Ammonium concentration variation as a function of time during the adsorption batch experiments with starting $p H$ of 4.94 and EC of $266 \mu \mathrm{S} / \mathrm{cm}$, sorbent (FAZ) dose of $0.25 \mathrm{~g}$, and SSA volume of $20 \mathrm{ml}$. SSA, synthetic solution A.

sorbents, although using the hydroxysodalite produced a strongly increase in concentration between 30 minutes and 1 hour, which has been also observed for $\mathrm{Zn}$ and $\mathrm{Pb}$. After 1 hour of reaction $\mathrm{Zn}, \mathrm{Ni}$ and $\mathrm{Pb}$ become stable. $\mathrm{Cu}$ and $\mathrm{Pb}$ probably were almost totally removed after this reaction time. $\mathrm{Cu}$ and $\mathrm{Zn}$ showed a reversal behaviour using Na-phillipsite (progressive increase) and K-chabazite (progressive decrease) after 2 hours of reaction. $\mathrm{Pb}$ displays a strongly reversible behaviour using these zeolitic materials, except when hydroxysodalite was used. Figures $4 \mathrm{~b}, 4 \mathrm{e}$ and $4 \mathrm{~h}$ show that very low levels of $\mathrm{Mg}$ were observed when Na-phillipsite and hydroxysodalite were used, whereas K-chabazite produced an increase after 5 minutes, then became stable with reaction time, except by a small decrease observed at 30 minutes and after 4 hours of reaction. $\mathrm{Ca}$ shows a strong reversible behaviour. In general, $\mathrm{Na}$ and $\mathrm{K}$ show an increase after 5 minutes and then show a progressive increase, although when K-chabazite was used it tends to be constant. In general, $\mathrm{Si}$ shows an irreversible behaviour and a progressive increase with reaction time, whereas Al displays a reversible behaviour (Figures 4c, 4f and 4i).

Ríos et al. (2008) have observed similar trends for FA-based faujasite used in the treatment of acid mine drainage and they consider that the main ge mechanism for metal uptake is precipitation of metal complexes on the surface of the sorbent and not sorption. Research has focused on the formation of precipitates in zeolite pores or surface, leading to pore clogging (Ackley et al., 1992; Vaca et al., 2001; Rodríguez-Iznaga et al., 2000). According to Inglezakis et al. (2003), the meso- and macropores as well as the irregular surface of the material could be considered as an appropriate environment for surface precipitation. Surface precipitation most probably reduces the ion-exchange ability of the zeolite due to the blockage of the micropores and most of the metals will be hydrolyzed and precipitated (Evangelou and Zhang, 1995).

\subsubsection{Effect of sorbent dose}

The effect of different doses of FAZs $(0.25,0.5$ and $1 \mathrm{~g} / 20 \mathrm{ml}$ ) on reduction of heavy metals and ammonium toxicity in polluted water was studied for $24 \mathrm{~h}$. $\mathrm{pH}$ showed a sudden increase after the addition of the sorbent, although it remains relatively unchanged (very small increase) as the sorbent dose was increased (Figure 5a). With the use of all sorbents, results show that EC gradually increased al the zeolite dose was increase (Figure $5 b)$. However, in spite of the dose, K-chabazite reached higher EC values than those obtained using the other sorbents. Hydroxysodalite 


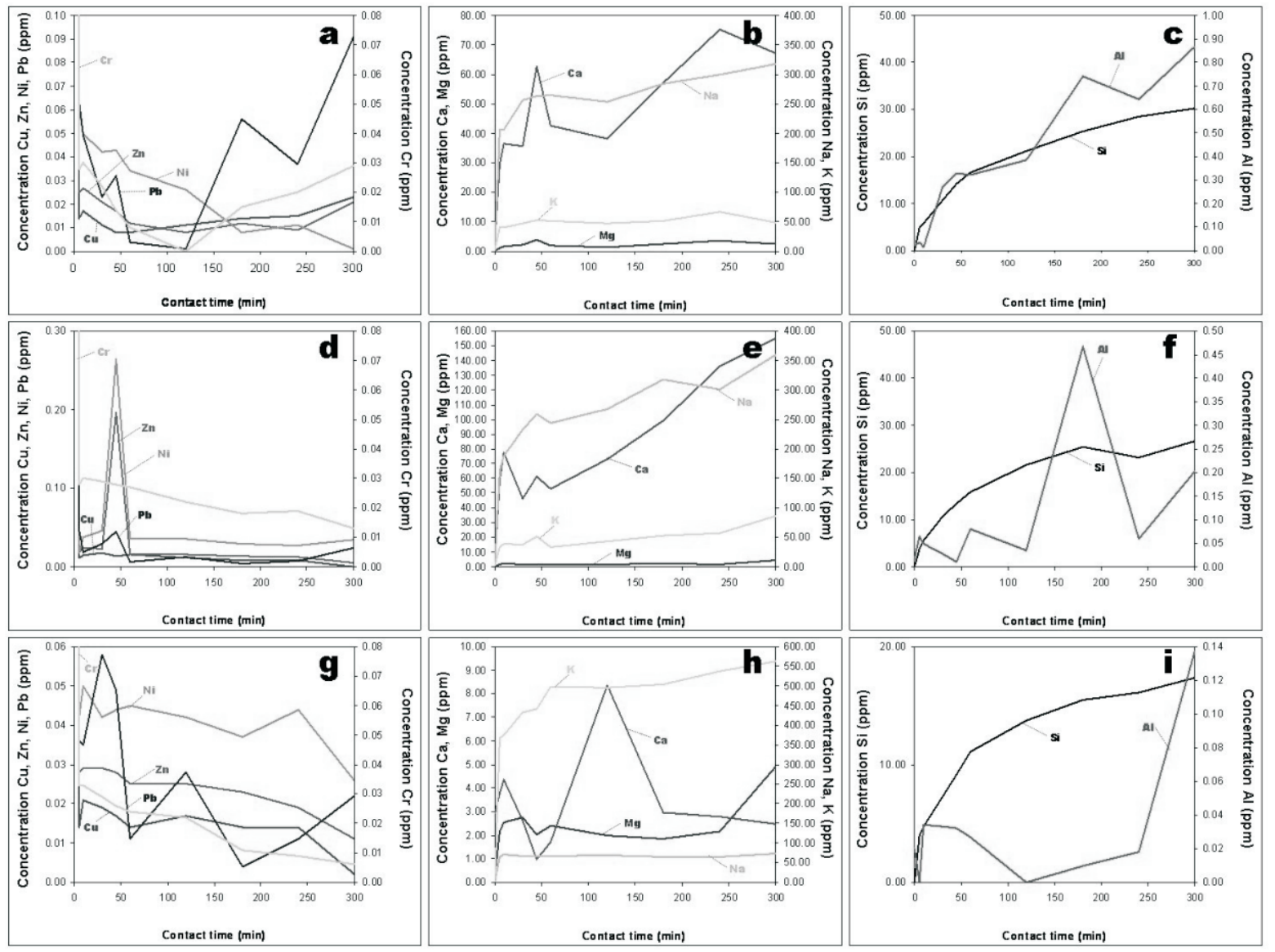

Figure 4. Elemental concentration variation as a function of time during the adsorption batch experiments with starting $p H$ of 4.94 and EC of $266 \mu \mathrm{S} / \mathrm{cm}$, sorbent (FAZ) dose of $0.25 \mathrm{~g}$, and SSA volume of $20 \mathrm{ml}$. SSA, synthetic solution A. (a-c), FA-based Naphillipsite; (d-f), FA-based hydroxysodalite; (g-i), FA-based K-chabazite.

produced higher EC values than Na-phillipsite, except when a highest dose was used.

The addition of K-chabazite (Figure 6a) indicates that $\mathrm{Cu}$ and $\mathrm{Zn}$ show the lower and higher residual concentrations using 0.25 and $0.5 \mathrm{~g}$ of sorbent, respectively. The increase of sorbent dose produced lower $\mathrm{Pb}$ residual concentrations. $\mathrm{Cr}$ displays an increase in the lower residual concentration with sorbent dose. The lower residual concentrations of $\mathrm{Ni}$ were obtained using a sorbent dose of $0.5 \mathrm{~g}$. Figure $6 \mathrm{~b}$ reveals that the use of Na-philipsite as sorbent produced the lower residual concentrations of $\mathrm{Cu}, \mathrm{Pb}, \mathrm{Zn}$ and $\mathrm{Ni}$ using $1 \mathrm{~g}$ of sorbent, whereas the higher residual concentrations of these heavy metals were observed with a sorbent dose of $0.5 \mathrm{~g}$. Cr shows a similar trend to that observed in Figure 6a. As shown in Figure 6c, all heavy metals display the lower residual concentrations using a sorbent dose of $1 \mathrm{~g}$, with the higher residual concentrations using $0.5 \mathrm{~g}$ of sorbent. Figure $6 \mathrm{~d}$ shows the results corresponding to the effect of FAZ dose on ammonium removal. All tested sorbents produced a decrease in ammonium concentration. Kchabazite produced the lower residual concentrations using 0.25 and $1 \mathrm{~g}$ of sorbent dose, with the higher residual concentrations with a sorbent dose of $0.5 \mathrm{~g}$; Na-phillipsite shows a reverse behavior. Hydroxysodalite shows a best efficiency in ammonium removal using the highest dose ( $1 \mathrm{~g})$, with a poor removal using 0.25 and $0.5 \mathrm{~g}$ of sorbet dose.

Results indicated that the adsorption percentage changed with the addition of a small amount of sorbent $(0.25 \mathrm{~g})$, whereas increasing the sorbent dose produced an increase in heavy metal and 

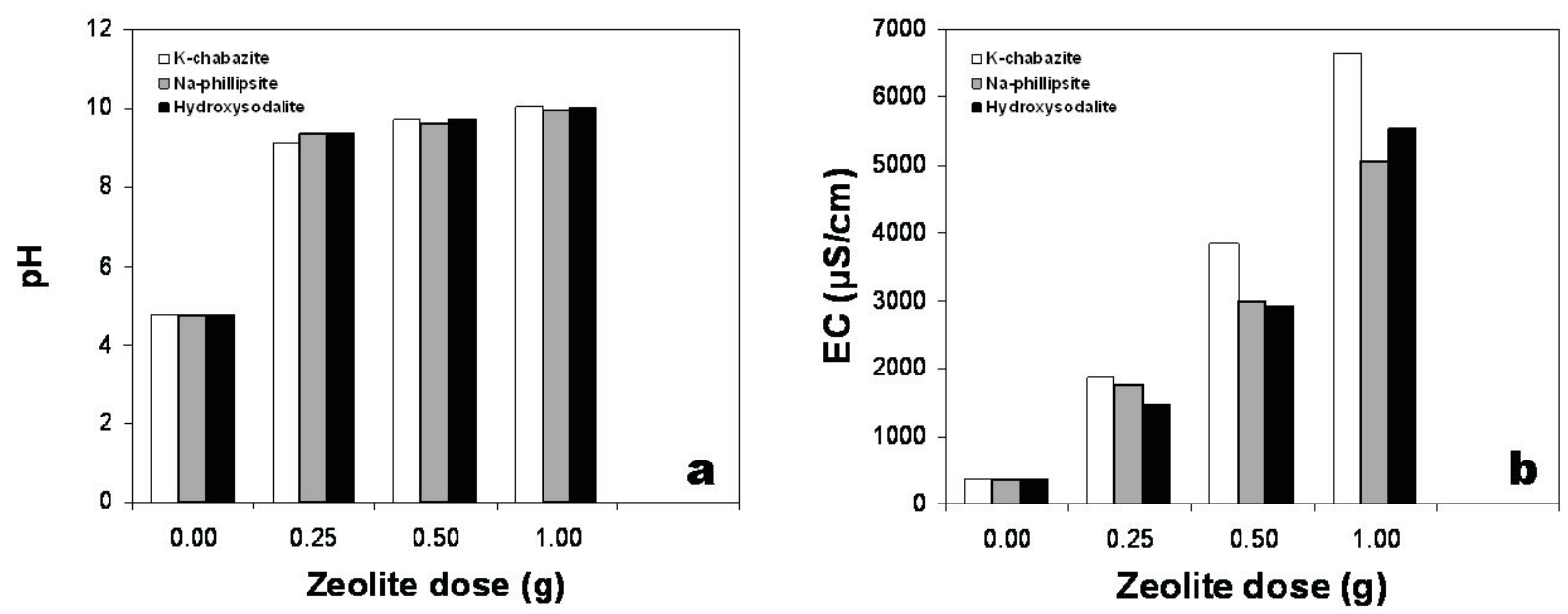

Figure 5. Effect of FAZ dose per $20 \mathrm{ml}$ on (a) $\mathrm{pH}$ and (b) EC.
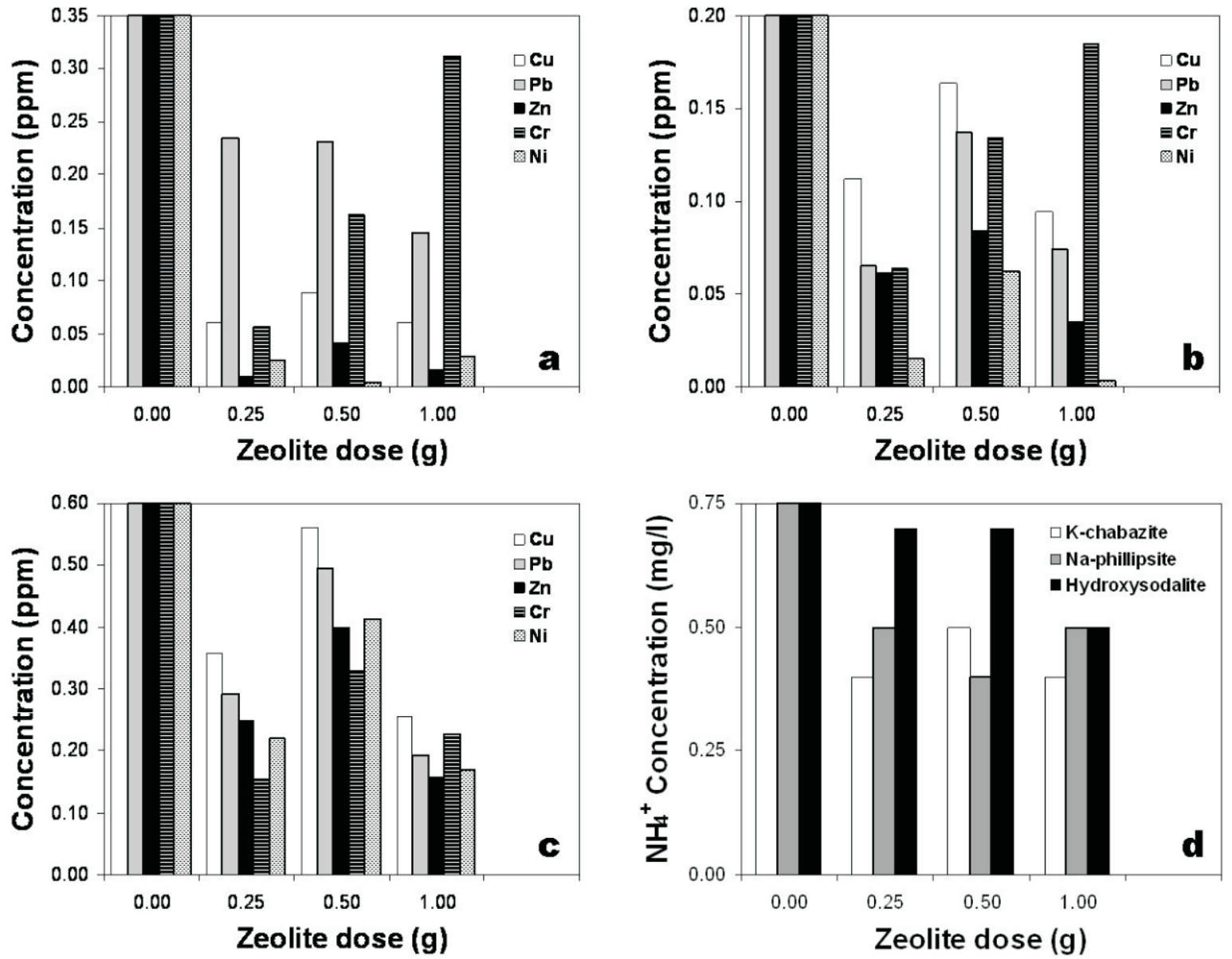

Figure 6. Effect of sorbent dose per $20 \mathrm{ml}$ on heavy metal concentration using (a) K-chabazite, (b) Na-phillipsite, (c) hydroxysodalite, and (d) $\mathrm{NH}_{4}^{+}$concentration using FAZs. 
ammonium concentration. A sharp increase in concentration was observed across a dose of $0.5 \mathrm{~g} /$ $20 \mathrm{ml}$, which can be explained by the fact that some ionic species went into solution. The higher heavy metal and ammonium removal can be explained by the greater availability of the exchangeable adsorption sites at the available larger sorbent surface area. The optimum zeolite amount was selected as $0.25 \mathrm{~g}$ per $20 \mathrm{ml}$ solution. Among the FAZs, K-chabazite shows a better performance.

An additional experiment was carried out using 1 $\mathrm{g}$ of FA and Na-phillipsite in $50 \mathrm{ml}$ for 7 days to establish long term behaviour of these sorbents in batch reactions. Table 2 summarizes the values of $\mathrm{pH}, \mathrm{EC}$ and concentration of metal ions in a untreated synthetic solution (SSB) and those of the leachates obtained by using a sorbent:SSB mixture of $1 \mathrm{~g} / 50 \mathrm{ml}$ during 7 days.

Figure 7 shows the $\mathrm{pH}$ and $\mathrm{EC}$ trends for the neutralization reactions between the synthetic solution and FA or Na-phillipsite. There was not observed breakthrough to alkaline $\mathrm{pH}$. The lack of buffering capacity for the SS1 can be attributed to the very low concentration of $\mathrm{Fe}^{3+} / \mathrm{Fe}^{2+}, \mathrm{Al}^{3+}, \mathrm{Mn}$ (Uhlmann et al., 2004).

The results obtained for the removal of metal ions from the synthetic solution are displayed in Figure 8. $\mathrm{Pb}$ and $\mathrm{Ni}$ are observed to decrease significantly when Na-phillipsite was reacted with the synthetic solution from 30 minutes to 3 hours, showing a complete removal after 3 hours. $\mathrm{Zn}$ was completely removed after 30 minutes. An initial increase in the $\mathrm{Cr}$ and $\mathrm{Cu}$ concentration was observed, followed by a decrease to reach a complete removal. The concentration of $\mathrm{K}$ shows a small decrease from 30 minutes to 1 hour, followed by gradual increases from 1 hour to 48 hours, and then it shows a small decrease with longer contact time. Ca shows a very different behaviour, with a decrease from 30 minutes to 6 hours, and then it increases from 6 to 48 hours, decreasing again with longer contact time.

From the above results, the FA was effective in reducing the $\mathrm{Cu}, \mathrm{Pb}, \mathrm{Zn}$ and $\mathrm{Ni}$ concentration, indicating the complete removal of these heavy metal, but not $\mathrm{Cr}$ as a consequence of the dominant occurrence of $\mathrm{Cr}(\mathrm{OH})_{4}^{-}$at $\mathrm{pH}>10$, which increases the solubility of $\mathrm{Cr}^{3+}$ in the FA. Different to the reversible exchange character observed for a wide spectrum of heavy metals, the exchange of $\mathrm{Cr}$ is strongly irreversible (Pansini and Colella, 1991; Loizidou et al., 1992). On the other hand, Naphillipsite shows a reversible character as revealed by the metal concentration fluctuations and in spite of showing a complete removal of all them, it was obtained only after 3 hours. Heavy metals were chemically incorporated into the FA and Na-phillipsite, but using the zeolitic product it was observed after a longer contact time, including $\mathrm{Cr}$, which can be reduced from the synthetic solution but not completely removed.

Table 2. Water quality parameters recorded during 7 days of continuous shaking of FA and Na-phillipsite with a synthetic solution in closed batch experiments (sorbent:SSB mixture of $1 \mathrm{~g} / 50 \mathrm{ml}$ ). SSB, synthetic solution B.

\begin{tabular}{|c|c|c|c|c|c|c|c|c|c|c|c|c|c|c|}
\hline \multirow{3}{*}{$\begin{array}{c}\begin{array}{c}\text { Contact time } \\
\text { (hour) }\end{array} \\
\text { SSB }\end{array}$} & \multirow{3}{*}{$\begin{array}{c}\mathrm{pH} \\
3.57\end{array}$} & \multirow{2}{*}{\multicolumn{2}{|c|}{$\mathrm{EC}(\mu \mathrm{S} / \mathrm{cm})$}} & \multicolumn{5}{|c|}{ Heavy metal concentration (ppm) } & \multicolumn{6}{|c|}{ Other element concentration (ppm) } \\
\hline & & & & \multirow{2}{*}{$\begin{array}{c}\mathrm{Cu} \\
7.40\end{array}$} & \multirow{2}{*}{$\frac{\mathrm{Pb}}{6.00}$} & \multirow{2}{*}{$\begin{array}{c}\mathrm{Zn} \\
6.04\end{array}$} & \multirow{2}{*}{$\begin{array}{c}\mathrm{Cr} \\
3.20\end{array}$} & \multirow{2}{*}{$\begin{array}{c}\mathrm{Ni} \\
5.89\end{array}$} & \multirow{2}{*}{$\begin{array}{l}\mathrm{Mg} \\
0.00\end{array}$} & \multirow{2}{*}{$\begin{array}{c}\mathrm{Ca} \\
2.08\end{array}$} & \multirow{2}{*}{$\begin{array}{c}\mathrm{Na} \\
52.22\end{array}$} & \multirow{2}{*}{$\begin{array}{c}\mathrm{K} \\
19.34\end{array}$} & \multirow{2}{*}{$\begin{array}{c}\mathrm{Si} \\
0.00\end{array}$} & \multirow{2}{*}{$\begin{array}{c}\text { Al } \\
0.03\end{array}$} \\
\hline & & 341 & $20.1^{\circ} \mathrm{C}$ & & & & & & & & & & & \\
\hline \multicolumn{15}{|c|}{ Batch reaction of $F A$} \\
\hline 0.5 & 11.95 & 1526 & $18.8^{\circ} \mathrm{C}$ & 0.00 & 0.00 & 0.00 & 0.11 & 0.00 & 0.00 & 103.09 & 7.46 & 23.50 & 0.91 & 0.44 \\
\hline 1 & 12.10 & 1789 & $18.7^{\circ} \mathrm{C}$ & 0.00 & 0.00 & 0.00 & 0.10 & 0.00 & 0.00 & 102.70 & 6.82 & 21.64 & 0.47 & 1.08 \\
\hline 3 & 12.07 & 1770 & $19.9^{\circ} \mathrm{C}$ & 0.00 & 0.00 & 0.00 & 0.08 & 0.00 & 0.00 & 102.54 & 7.06 & 23.21 & 2.17 & 5.49 \\
\hline 6 & 12.10 & 1964 & $22.3^{\circ} \mathrm{C}$ & 0.00 & 0.00 & 0.00 & 0.10 & 0.00 & 0.00 & 102.58 & 6.31 & 22.85 & 0.35 & 0.26 \\
\hline 24 & 12.13 & 2288 & $21.2^{\circ} \mathrm{C}$ & 0.00 & 0.00 & 0.00 & 0.11 & 0.00 & 0.00 & 104.58 & 6.01 & 21.31 & 1.95 & 0.74 \\
\hline 48 & 12.09 & 2392 & $22.4^{\circ} \mathrm{C}$ & 0.00 & 0.00 & 0.00 & 0.15 & 0.00 & 0.00 & 102.94 & 7.27 & 21.80 & 0.80 & 0.40 \\
\hline 168 & 11.92 & 1830 & $23.3^{\circ} \mathrm{C}$ & 0.00 & 0.00 & 0.00 & 0.19 & 0.00 & 0.00 & 103.45 & 7.91 & 23.62 & 3.33 & 1.78 \\
\hline \multicolumn{15}{|c|}{ Batch reaction of Na-phillipsite } \\
\hline 0.5 & 10.33 & 1790 & $23.6^{\circ} \mathrm{C}$ & 0.01 & 0.02 & 0.00 & 0.00 & 0.02 & 0.00 & 19.40 & 509.61 & 11.80 & 36.93 & 1.53 \\
\hline 1 & 10.31 & 1639 & $23.3^{\circ} \mathrm{C}$ & 0.03 & 0.01 & 0.00 & 0.01 & 0.00 & 0.00 & 16.61 & 467.11 & 11.22 & 48.17 & 2.39 \\
\hline 3 & 10.37 & 1710 & $24.6^{\circ} \mathrm{C}$ & 0.00 & 0.00 & 0.00 & 0.00 & 0.00 & 0.00 & 10.92 & 485.07 & 11.57 & 72.00 & 0.45 \\
\hline 6 & 10.38 & 1760 & $26.5^{\circ} \mathrm{C}$ & 0.00 & 0.00 & 0.00 & 0.00 & 0.00 & 0.00 & 10.23 & 426.89 & 12.24 & 80.25 & 0.38 \\
\hline 24 & 10.45 & 1879 & $24.7^{\circ} \mathrm{C}$ & 0.00 & 0.00 & 0.00 & 0.00 & 0.00 & 0.00 & 17.53 & 538.86 & 13.64 & 93.11 & 0.39 \\
\hline 48 & 10.48 & 1963 & $24.8^{\circ} \mathrm{C}$ & 0.00 & 0.00 & 0.00 & 0.00 & 0.00 & 0.00 & 18.26 & 552.52 & 13.89 & 99.89 & 0.00 \\
\hline 168 & 10.56 & 1836 & $21.4^{\circ} \mathrm{C}$ & 0.00 & 0.00 & 0.00 & 0.00 & 0.00 & 0.00 & 11.70 & 521.81 & 12.86 & 103.95 & 0.00 \\
\hline
\end{tabular}

SSB, synthetic solution B 

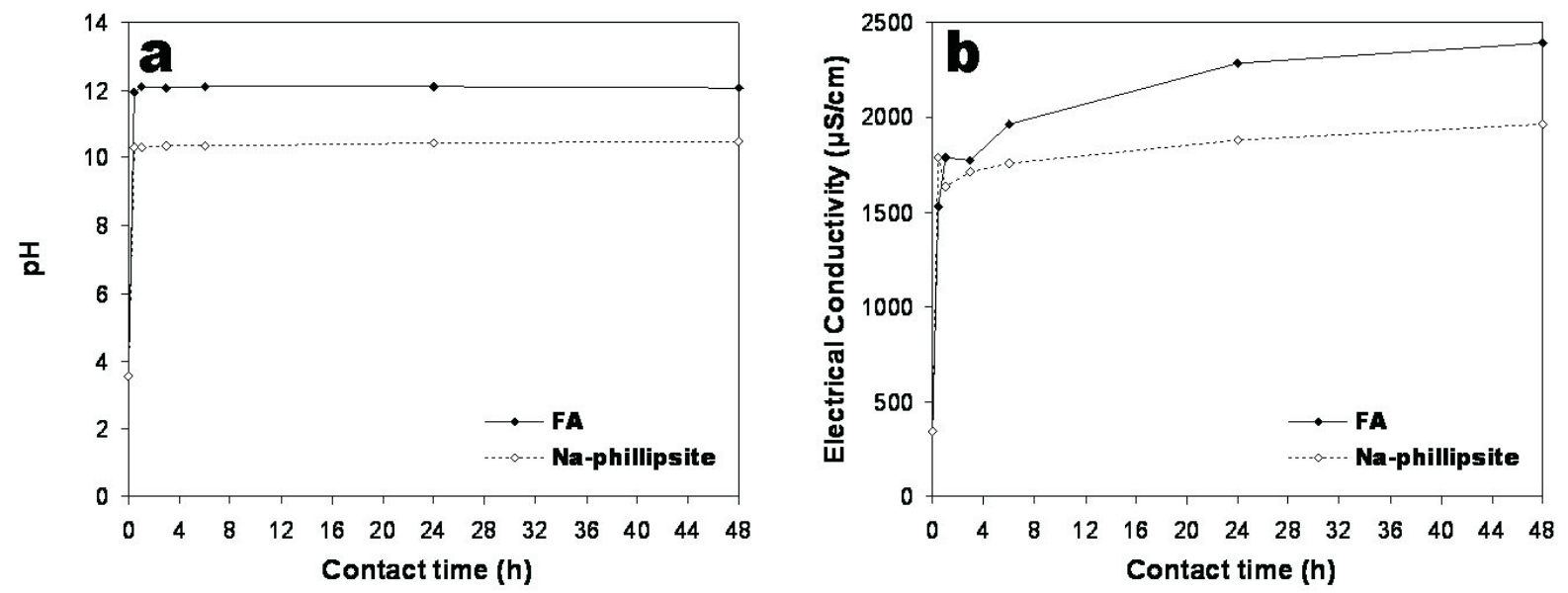

Figure 7.pH (a) and EC (b) variation as a function of time during adsorption batch experiments with starting $p H$ of 3.57 and $E C$ of $341 \mu \mathrm{S} / \mathrm{cm}$, sorbent (FA and Na-phillipsite) dose of $1 \mathrm{~g}$, and SSB volume of $50 \mathrm{ml}$. SSB, synthetic solution B.
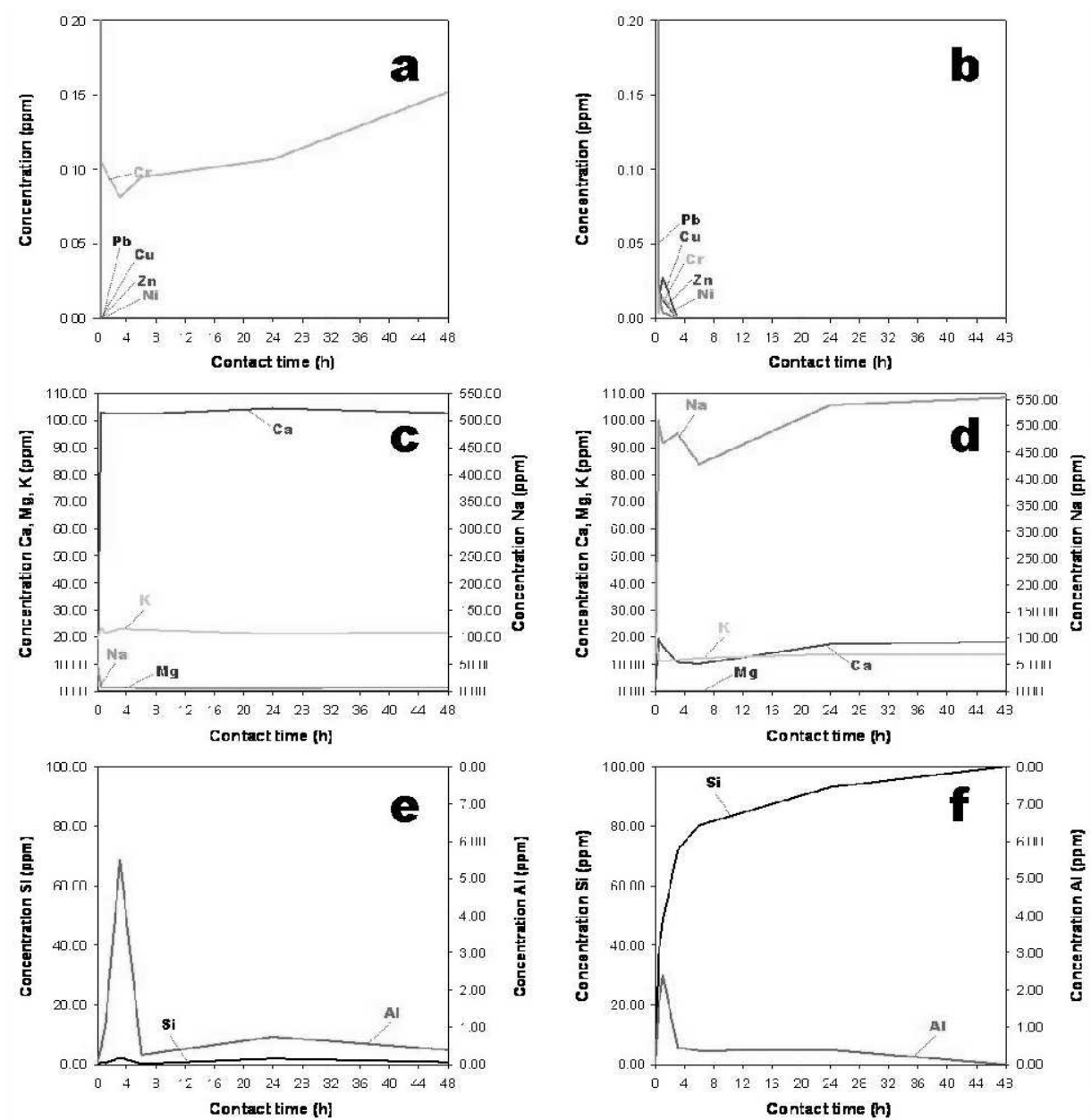

rigure 8. Heavy metal ana other element concentratlon vartatlon as a Junction of tıme during adsorption batch experiments with starting $\mathrm{pH}$ of 3.57 and EC of $341 \mu \mathrm{S} / \mathrm{cm}$, sorbent (FA and Na-phillipsite) dose of $1 \mathrm{~g}$, and SSB volume of $50 \mathrm{ml}$. SSB, synthetic solution $B$. 
Figure 9 shows the efficiency of Na-phillipsite in the removal of $\mathrm{N}, \mathrm{P}, \mathrm{Cl}^{-}, \mathrm{NO}_{3}^{-}, \mathrm{PO}_{4}^{3-}$ and $\mathrm{SO}_{4}^{2-}$. This zeolitic product produced a decrease in ammonium, nitrate and chloride during the first 2 hours, although a steep decrease in chloride during the first hour was observed. Between 2 and 3 hours, these contaminants increased and then stabilized with reaction time. Sulphate and phosphate show a strong reversible behavior, although after 3 hours the last of them progressively decreases with reaction time.

There are several factors that influence the sorption capacity of the ion exchangers used in this study, such as total capacity, concentration and type of ions to be sorbed, site accessibility, $\mathrm{pH}$ variation, temperature and rate of agitation (Helfferrich, 1962). On the other hand, Hendricks (2005) describes additional aspects playing a very important role in the reaction between a specific sorbent and the aqueous media, which include competing ions and interactions between sorbent and metal ions. In addition to the exchangeable metal contaminants to be removed, there are other species which will interfere with the ion exchange process by competing for the available exchange sites on the ion exchanger and as such, may adversely affect the process and therefore it is thus beneficial to investigate the effect of competing ions, on the metal loading onto a given ion exchanger. There is also important to understand the dynamics involved in the reaction in the sorbent:solution interface, which should consider interactions such as ion exchange, surface hydrolysis, hydration, competing exchange reactions between metal ions in solution and free hydronium ions $\left(\mathrm{H}^{+}\right)$.

\subsection{Ion exchange capacity}

The application of FAZs in water purification has been developed for especific pollutants by using synthetic solutions at laboratory scale, showing that the zeolitic material obtained may reach appropriate values of $\mathrm{CEC}$ and that there is a competition between cations in solution to occupy exchangeable sites in zeolites (Querol et al., 2002). In this study we have synthesized different zeolitic materials from FA. However, Naphillipsite was selected for ion exchange after introducing ammonium $\left(\mathrm{NH}_{4}^{+}\right)$into its framework. The results from ICP-AES analysis are illustrated in Figure 10.

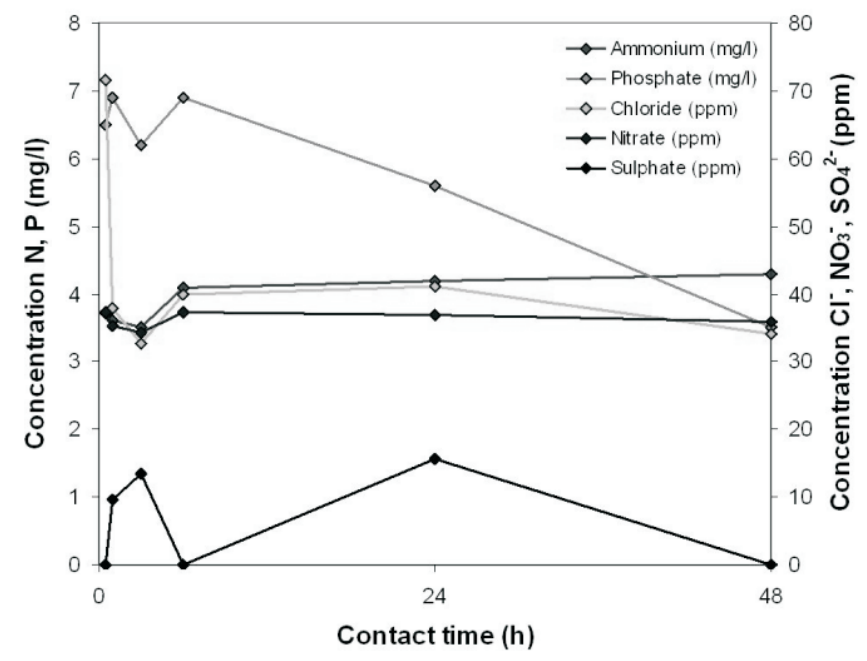

Figure 9. Concentration variation of anion complexes as a function of time during adsorption batch experiments with starting pH of 3.57 and EC of $341 \mu \mathrm{S} / \mathrm{cm}$, sorbent (FA and Na-phillipsite) dose of $1 \mathrm{~g}$, and $S S B$ volume of $50 \mathrm{ml}$. SSB, synthetic solution $B$. 
The experiment of ion exchange of Na-phillipsite, using ammonium acetate $(0.5 \mathrm{M})$, repeating the ion exchange five times (each one for 25 minutes) is summarized as follows. A high decrease in $\mathrm{Na}^{+}$ concentration and a small decrease in $\mathrm{K}^{+}$ concentration with each wash were observed. $\mathrm{Na}^{+}$ was very rapidly exchanged by $\mathrm{NH}_{4}^{+}$in the zeolite framework. $\mathrm{Al}^{3+}$ concentration presents the contrary behaviour, showing a high increase between the first and the third washing and then decreases, which indicates that $\mathrm{Al}^{3+}$ had been brought into solution during ion exchange. The abnormal behaviour of aluminium could be related to a sudden change in $\mathrm{pH}$ conditions. The results showed that there is no significant ion exchange on silicon, taking into account that its concentration is constant.

\section{Conclusions}

The present study showed that the as-synthesized FAZ sorbents were effective in removing mixed heavy metals and ammonium from artificially polluted solutions. The results obtained, particularly for short contact times suggests that the use of FAZs for the removal of metal ions from effluents contaminated with mixed heavy metals might became interesting in other different industrial applications. The as-synthesized FAZs had greater adsorption capabilities for heavy metals and ammonium than the original FA. Na- phillipsite exhibited the highest adsorption capacity with a metal ion selectivity of $\mathrm{Cu}>\mathrm{Zn}>\mathrm{Cr}>\mathrm{Ni}>\mathrm{Pb}$. Our experimental data suggest that the FA could be converted into a beneficial product, which will be used in the future as an ion exchanger in removing heavy metals from wastewaters. Therefore, it is necessary to develop further experiments under well-optimized conditions, to successfully prepare highly crystalline zeolites. For this purpose, a search for new applications for FA is underway. The production of zeolites from FA could constitute an alternative and noble use for a residue which has historically contributed for the degradation of large areas located in the Sttaffordshire county.

\section{Acknowledgments}

This research was supported by the Programme Alban, 'the European Union Programme of High Level Scholarships for Latin America' (Scholarship No. E05D060429CO), and the Universidad Industrial de Santander (remunerated commission) for funding C.A. Ríos, and has benefited from research facilities provided by the School of Applied Sciences at the University of Wolverhampton. We thank to Dr. David Townrow and Mrs. Barbara Hodson for assistance with XRD and SEM data acquisition, respectively.
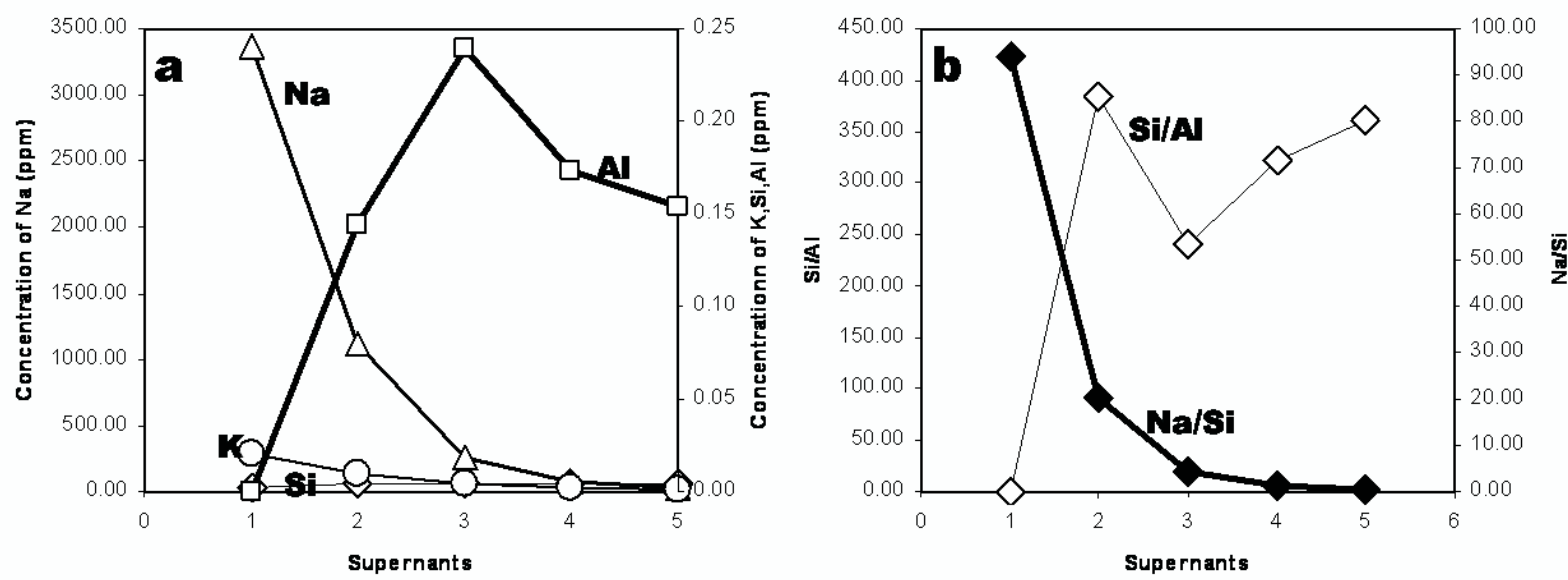

Figure 10. (a) Na, K, Si and Al concentration in leachates and (b) Si/Al and Na/Si ratios after ion exchange of Naphillipsite. 


\section{References}

Amrhein, C., Haghnia, G.H., Kim, T.S., Mosher, P.A., Gagajena, R.C., Amanios, T., \& De La Torre, L. (1996). Synthesis and properties of zeolites from fly ash. Environmental Science Technology 30(3), 735-742.

Evangelou, V.P., \& Zhang, Y.L. (1995). A review: Pyrite oxidation mechanisms and acid mine drainage prevention. Critical Reviews in Environmental Science Technology 25(2), 141199.

Genç-Fuhrman, H., Mikkelsen, P.S., \& Ledin, A. (2007). Simultaneous removal of As, Cd, Cr, Cu, $\mathrm{Ni}$ and $\mathrm{Zn}$ from stormwater: Experimental comparison of 11 different Sorbents. Water Research 41(3), 591-602.

Gitari, M.W., Petrik, L.F., Etchebers, O., Key, D.L., Iwuoha, E.I., \& Okujeni, C. (2006). Treatment of acid mine drainage with fly ash: removal of major contaminants and trace elements. Journal of Environmental Science and Health, Part A: Toxic/Hazardous Substances and Environmental Engineering 41(8), 1729-1747.

Helfferrich, F. (1962). Ion exchange: McGrawHill Series in Advanced Chemistry. New York: McGraw-Hill Book Company, Inc.

Hendricks, N.R. (2005). The application of high capacity ion exchange adsorbent material, synthesized from fly ash and acid mine drainage, for the removal of heavy and trace metals from secondary co-disposed process waters. Master thesis, University of the Western Cape.

Höller, H., \& Wirsching, U. (1985). Zeolite formation from fly ash. Fortschritte der Mineralogie 63(1), 21-43.

Inada, M., Eguchi, Y., Enomoto, N., \& Hojo, J. (2005). Synthesis of zeolite from coal ashes with different silica-alumina composition. Fuel 84(23), 299-304.
Inglezakis, V.J., Zorpas, A.A., Loizidou, M.D., \& Grigoropoulou, H.P. (2003). Simultaneous removal of metals $\mathrm{Cu}^{2+}, \mathrm{Fe}^{3+}$ and $\mathrm{Cr}^{3+}$ with anions $\mathrm{SO}_{4}^{2-}$ and $\mathrm{HPO}_{4}^{2-}$ using clinoptilolite. Microporous and Mesoporous Materials 61(1-3), 167-171.

Juan, R., Hernández, S., Andrés, J.M., \& Ruiz, C. (2007). Synthesis of granular zeolitic materials with high cation exchange capacity from agglomerated coal fly ash. Fuel 86(12-13), 18111821.

La Rosa, J.L., Kwan, S., \& Grutzeck, M.W. (1992). Zeolite Formation in Class F Fly Ash Blended Cement Pastes. Journal of the American Ceramic Society 75(6), 1574-1580.

Lin, C.-F., \& His, H.-C. (1995). Resource recovery of waste fly ash: Synthesis of zeolite-like materials. Environmental Science Technology 29(4), 1109-1117.

Loizidou, M., Haralambous, K., Loukatos, A., \& Dimitrakopolou, D. (1992). Natural zeolites and their ion exchanger behavior towards chromium. Journal of Environmental Science and Health, Part A: Toxic/Hazardous Substances and Environmental Engineering 27(7), 1759-1769.

Mier, M.V., Callejas, R.L., Gehr, R., Cisneros, B.E.J., \& Alvarez, P.J.J. (2001). Heavy metal removal with Mexican clinoptilolite: multicomponent ionic exchange. Water Research 35(2), 373-378.

Mondragón, F., Rincón, F., Sierra, L., Escobar, J., Ramírez, J., \& Fernández, J. (1990). New perspectives for coal ash utilization: Synthesis of zeolitic materials. Fuel 69(2), 263-266.

Moreno, N., Querol, X., Ayora, C., Alastuey, A., Fernández-Pereira, C., \& Janssen, M. (2001). Potential Environmental Applications of Pure Zeolitic Material Synthesized from Fly Ash. Journal of Environmental Engineering 127(11), 994-1002. 
Ojha, K., Pradhan, N.C., \& Samanta, A.N. (2004). Zeolite from fly ash: synthesis and characterization. Bulletin of Material Science 27(6), 555-564.

Ouki, S.K., \& Kavannagh, M. (1997). Performance of natural zeolites for the treatment of mixed metal-contaminated effluents. Waste Management \& Research 15(4), 383-394.

Pansini, M., \& Colella, C. (1991). Optimization of the process of $\mathrm{Cr}^{3+}$ removal from wastewaters by direct addition of natural zeolites, Proc. I Convegno Naz. di Scienza e Tecnologia delle zeoliti, C. Colella ed., 131-137, Napoli.

Pitcher, S.K., Slade, R.C.T., \& Wards, N.I. (2004). Heavy metal removal from motorway stormwater using zeolites. Science of the total environment 334-335(1), 161-166.

Querol, X., Moreno, N., Umaña, J.C., Alastuey, A., Hernández, E., López-Soler, A., \& Plana, F. (2002a). Synthesis of zeolites from fly ash: an overview. International Journal of Coal Geology 50(1-4), 413-423.

Querol, X., Moreno, N., Umaña, J.C., Juan, R., Hernández, S., Fernandez-Pereira, C., Ayora, C., Janssen, M., García-Martínez, J., Linares-Solano, A., \& Cazorla-Amoros, D. (2002b). Application of zeolitic material synthesized from fly ash to the decontamination of waste water and flue gas. Journal of Chemical Technology \& Biotechnology 77, 292-298.
Ríos, C.A., Williams, C.D., \& Roberts C.L. (2008). Removal of heavy metals from acid mine drainage (AMD) using coal fly ash, natural clinker and synthetic zeolites. Journal of Hazardous Materials 156(1-3), 23-35.

Rodríguez-Iznaga, I., Rodríguez-Fuentes, G., \& Benitez-Aguilar, A. (2000). The role of carbonate ions in the ion-exchange $\mathrm{Ni}^{2+}=2 \mathrm{NH}_{4}^{+}$in natural clinoptilolite. Microporous and Mesoporous Materials 41(1-3), 129-136.

Shih, W.-H., \& Chang, H.-L. (1996). Conversion of fly ash into zeolites for ion-exchange application. Material Letters 28(4-6), 263-268.

Singer, A., \& Berkgaut, V. (1995). Cation exchange properties of hydrothermally treated coal fly ash. Environmental Science Technology 29(7), 1748-1753.

Uhlmann, W., Buttcher, H., Totsche, O., \& Steinberg, C.E.W. (2004). Buffering of acidic mine lakes: The relevance of surface exchange and solid bound sulphate. Mine Water Environment 23(1), 20-27.

Wingenfelder, U., Hansen, C., Furrer, G., \& Schulin, R. (2005). Removal of heavy metals from mine waters by natural zeolites. Environmental Science Technology 39(12), 4606-4613.

Woolard, C.D., Strong, J., \& Erasmus, C.R. (2002). Evaluation of the use of modified coal ash as a potential sorbent for organic waste streams. Applied Geochemistry 17(8), 1159-1164. 